\title{
A Language Teacher in the ESP Classroom: Can We be a Successful Dweller in This Strange and Uncharted Land?
}

\author{
Suphatha Rachayon ${ }^{1}$ \\ ${ }^{1}$ Faculty of Liberal Arts, Huachiew Chalermprakiet University, Samut Prakarn, Thailand \\ Correspondence: Suphatha Rachayon, Faculty of Liberal Arts, Huachiew Chalermprakiet University, Samut \\ Prakarn, Thailand.
}

Received: July 25, 2020

Accepted: August 27, 2020

Online Published: August 28, 2020

doi: 10.5539/elt.v13n9p119

URL: https://doi.org/10.5539/elt.v13n9p119

\begin{abstract}
The English for specific purposes (ESP) classroom has been described by a number of scholars as a strange and uncharted land for many language teachers. This is because ESP is designed to meet the specific needs of the learner, making it related to subject specialist content. Accordingly, some people feel that language teachers without a specialist subject background are "unqualified" to teach ESP courses. Rather, subject specialists should be the ones who teach these courses even though, in many cases, they are not trained to teach language. This paper therefore aims to find out whether it is possible that language teachers, who have limited subject specialist knowledge, can "settle down" happily in this strange and uncharted land. Reviews of the literature and previous studies of related topics, namely the definition of ESP, subject specificity, subject specialist knowledge, strategies for dealing with a lack of subject specialist knowledge, and the roles of the ESP practitioner, are discussed first. Then, the answer to the question is presented at the end.
\end{abstract}

Keywords: English for specific purposes, subject specialist knowledge, roles of an ESP practitioner

\section{Introduction}

Hutchinson and Waters (1987) describe the English for specific purposes (ESP) classroom as a strange and uncharted land. It is a land which, Belcher (2006) says, is intimidating for many language teachers. Their description is not exaggerated at all if we try to imagine what usually happens in an ESP classroom. In our imagination, we will see ourselves as a language teacher standing in front of the class and trying to explain something that we are not completely familiar with. The situation will be worse when students know a lot more than us and begin to discuss the topics with their classmates and then begin to ask questions that we cannot answer. This situation occurs because we do not have the knowledge that our students have, subject specialist knowledge. Thus, it seems that most language teachers tend to prefer teaching general English courses (GE), in which they feel "safe" to a certain extent because they tend to have some experience being students in these classes (Ferguson, 1997). Moreover, some people also feel that language teachers without a specialist subject background are "unqualified" to teach ESP courses. Rather, subject specialists should be those that take over these courses even though, in many cases, they are not trained to teach language (Howell, 2009).

This situation has also occurred at my workplace, a private university in Samut Prakarn province in Thailand. Each year, the department of English offers many ESP courses for students from diverse faculties and departments, such as Business English, English for Scientists, English for Tour Guides, English for Medical Technologists, or English for Public Health. All of these courses were taught by English teachers until a few years ago when the subject teachers wanted to teach language to their students themselves. The first ESP course that was lost was English for Law. I still remember that all of my colleagues, at that time, felt relieved that they did not have to teach this course any longer, explaining that they were not confident because they did not have knowledge about law. We then lost English for Physical Therapists I and II in the following year, and we are going to lose English for Public Health in the coming year. The only reason that they want to teach their students themselves is because they feel that they, with specialist knowledge, will be able to teach ESP better than us, even though they have no idea about how to teach English.

This situation leads us to two questions: "Do we need to be a subject specialist in order to teach ESP effectively?" and "Is it possible that we, who have limited subject specialist knowledge, can settle down happily in this strange and uncharted land?" 
In order to answer these questions, the review and discussion of related literature and previous studies are presented according to the topics as follows: a definition of ESP, subject specificity, subject specialist knowledge, strategies for dealing with the lack of subject specialist knowledge, and the roles of an ESP practitioner.

\section{A Definition of ESP}

Many scholars have proposed a definition of ESP. One of the most quoted definitions was proposed by Hutchinson and Waters (1987). In their point of view, ESP is considered as an approach to language teaching and learning rather than as any particular language product. Specifically, it should be an approach which is directed by the students' specific reasons for learning English.

In the following year, ESP was defined more clearly by Strevens (1988). He put forward the idea that ESP should have four absolute characteristics. First, ESP is designed to meet the learners' specific needs. Its content is then correlated with particular disciplines, occupations, and activities. However, the focus must be on language that is appropriate to those activities in terms of syntax, lexis, discourse, semantics, and so on, and the analysis of discourse. Lastly, ESP should be different from general English. These key aspects of ESP are in line with the definition stated by Dudley-Evans and St. John (1998). Their definition also emphasizes that ESP should be designed to meet the specific needs of the learners, employ the underlying methodology and activities of certain disciplines, and be based on the language, skills, discourse, and genres relevant to these activities.

Based on these definitions, it can be seen that what they all have in common is the focus of ESP on language and not the subject matter. Hence, ESP is obviously the job of language teachers and not of subject specialists. For this point of view, it can be concluded that, as language teachers, it is our duty to explore this strange and uncharted land; it is our duty to teach an ESP course.

However, there is another important element appearing in these definitions, which is that in ESP the language is taught based on the specific needs of the students. That is, the content of an ESP course comes from students' needs. However, the word "specific" is not defined clearly in these definitions. More literature related to subject specificity is, then, reviewed in the next section.

\section{Subject Specificity}

Many experts have expressed ideas about specificity in ESP. According to Belcher (2006), the specificity in ESP depends on whether the conceptualization of the language and task-proficiencies that learners need is performed widely or narrowly.

In a wide-angled approach, learners' language and task-proficiency needs are conceptualized as common-core language and language-learning strategies for an ever-expanding realm of unpredictable domains and tasks. According to the "wide-anglers," such as Widdowson (1983) and Hutchinson and Waters (1987), many aspects in English for academic purposes are not different across the array of disciplines. Thus, it is more efficient to produce instructional materials that can be shared among students from different disciplines.

"Narrow-anglers" such as Dudley-Evans and St. John (1998), and Hyland (2002), on the other hand, view the language and task-proficiencies needed by learners as immediately useful domain-specific language and related tasks. Accordingly, focusing mainly on the common-core aspects of academic English in ESP classes seems to be questionable for them. Furthermore, in many cases, students are likely to be more motivated if ESP classes can help them keep up with lectures or help them do homework or assignments in the other classes that they are attending. This tends to benefit students more than just teaching them generalized strategies for listening comprehension or academic writing. Additionally, according to discourse analysis, there is clear evidence that within a specific discipline, even closely related disciplines, there are particular features that distinguish it from other (Dudley-Evans, 1997).

Now one may ask which approach is better. According to Belcher (2006), the decision on which approach, either wide or narrow, should be applied to each ESP class should be based on the learners themselves, not on the instructors' preferences or beliefs. That is, a wide approach may be more appropriate and more beneficial for low-proficiency level adults and undergraduates without majors, while other learners that have had some subject or professional knowledge, such as graduate students, pilots, or nurses, may benefit more from a narrower approach.

However, Dudley-Evans and St. John (1998) point out that although no matter whether a wide or a narrow approach is implemented in an ESP class, and whether its focus is on language and not the subject matter, some specific carrier content should be included in any ESP classes. Moreover, Anthony (2011) believes that if a language teacher has to teach narrow-angled, subject-specific ESP, he or she might face more problems (compared to a wide-angle approach) because language teachers are not very familiar with the disciplines of the 
learners; it is most likely that learners know more about the content than the teacher (Spack, 1988). As Belcher (2009: 11) describes, this is one of the most daunting aspects of the ESP approach for a teacher.

This therefore leads to another interesting question: How much subject specialist knowledge is "enough" for us, language teachers, in order to be able to teach ESP course effectively? In order to find the answer to this question, the literature related to subject specialist knowledge is reviewed and discussed in the next section.

\section{Subject Specialist Knowledge}

The term "subject specialist knowledge," according to Ferguson (1997), is typically constructed as knowledge of the subject matter of the learners' discipline or profession. The role of specialist knowledge in ESP teaching has been explored in three ways, namely in theoretical argumentation, in empirical research studies, and in practical accounts.

In theoretical arguments, there is a great deal of evidence demonstrating the need for specialist knowledge in ESP teaching. Bhatia et al. (1997), for example, have argued for authenticity in text-task relationships. They assert that the texts used in ESP class can be considered as authentic only if the teachers know the status and roles of those texts in the specialist discourse community. For instance, an authentic legal case has a particular function in the legal discourse community and is read merely for particular purposes. Thus, if teachers want to use it in an ESP class, they should be aware of this and should not treat it as an ordinary narrative. Some linguists such as Halliday (1994) and Myers (1991) also agree that specialist knowledge is necessary in teaching ESP courses. Halliday (1994) states that some semantic information tends to be lost in the formation of the noun compounds and nominalizations that typically appear in most scientific writing. This is because the semantic relations are mostly left implicit in these texts and are easily seen by specialists using their background knowledge. However, these links are still blurred for non-specialists. Similarly, Myers (1991) notes that specialist background knowledge is also needed in order to understand the cohesion within the text in scientific discourse since the cohesion in these texts is inexplicit as well.

In addition to the arguments above, there are some research studies that have looked into the need of an ESP teacher to have specialist knowledge. For example, the finding of Selinker's study (1979) suggested that an ESL teacher needs to understand the main concepts and presuppositions of the text; otherwise, he/she will tend to focus on lower-level features of grammar and vocabulary. Similarly, studies conducted by White in 1981 and Zuck and Zuck in 1984 also showed that when an EFL teacher and a specialist read the same text, they comprehended it in different ways. That is, EFL teachers tended to focus on low-level factual details whereas specialists were likely to focus on something more global, requiring more inferences.

Further, the role of specialist knowledge in ESP teaching is also explored through classroom research for example in the studies conducted by Sheerin in 1981 and Ferguson in 1991. In these studies, it was found that specialist knowledge is useful, but teachers could use certain strategies in order to overcome their lack of it and achieve satisfactory lessons. However, these studies are only on a small-scale, and thus probably have problems regarding generalization (Ferguson, 1997).

Based on all of the evidence mentioned above, we can see that subject specialist knowledge somehow facilitates ESP teaching. Although some studies have shown that certain strategies can be used by language teachers to mitigate their lack of specialist knowledge, I believe that as an ESP teacher, we cannot teach well if we do not have any knowledge about the subject matter at all since it is the context of the lesson that we teach. Thus, in order to teach an ESP class, we need to have knowledge about the subject matter. Knowing that we need subject specialist knowledge when teaching an ESP, now we come to the most frequently asked question: "How much specialist knowledge should we have?"

Ewer (1983) suggests that the ESP teacher should be willing to acquire an intelligent layman's outline knowledge of the disciplines that his or her students are studying. This is in line with Dudley-Evans (1997) and Adams-Smith (1983), who believe that ESP teachers need to be interested in the discipline. Additionally, they should be willing to explore the genre conventions but do not need to have detailed knowledge of the actual content. Moreover, they need to try to find out how the discipline works and what sorts of questions they are seeking answers to rather than necessarily knowing or understanding all of the answers. The ability of ESP teachers to ask intelligent questions is also emphasized by Hutchinson and Waters (1987). According to them, the ESP teacher should not become a teacher of the subject matter but rather be an interested student of the subject matter. In order to become an interested student of the subject matter, he/she needs to possess three things: a positive attitude toward the ESP content, knowledge of the fundamental principles of the subject area, and awareness of how much they probably already know. Based on the ideas above, it can be concluded that an ESP teacher needs to have fundamental knowledge about the subject matter. Moreover, he/she needs a positive 
attitude toward the ESP content, meaning that he or she has to be interested in the subject and be willing to learn more.

However, since language teachers are trained in the humanities, receiving little or no education in the sciences, it seems that teaching an ESP class, which requires only fundamental knowledge of the subject matter, sometimes can cause problems. In the next section, then, we will see what strategies that ESP teachers use when they face unpredicted problems in a subject during class.

\section{Strategies for Dealing with Lack of Subject Knowledge}

There is a very small number of research studies related to the issue of the strategies that ESP teachers use for dealing with lack of subject knowledge.

The first research was conducted in 2009 by Wu et al. They investigated how three ESP teachers responded to unpredicted situations in the classrooms where their subject knowledge was limited-a situation that they called "In-class Subject Knowledge Dilemma" (ISKD) situations. The data were collected through a number of research instruments; namely, an unstructured interview, classroom observations, stimulated recalls, and semi-structured post-observation interviews. The results showed that when teachers had to deal with an unplanned subject knowledge problem, they either avoided the question or took a risk. The tactics that they used for avoidance were to move to the next topic, change example sentences, and focus on morphology. The tactics for risk taking were literal translation and asking students. The study also found that the teachers believed that such unpredicted problems reflected poorly on their competence as teachers. However, the strategies they adopted helped the lesson to run smoothly, preventing them from losing face while still maintaining their students' respect as experts in the field.

Another research was conducted in 2013 by three Iranian researchers. In their study, they investigated the strategies that five Iranian ESP teachers adopted in order to cope with situations when they faced a problem of lacking subject specialist knowledge. By observing the teachers' classes, they found that in order to compensate for their lack of knowledge the teachers utilized a number of strategies, including avoidance, risk-taking, and admitting ignorance. In the stimulated recall interviews, most of the teachers stated that they used such strategies to maintain face and respect, which is quite similar to the result from the first research study. In addition to the first study, this study also examined the students' viewpoints regarding their teachers' subject area knowledge and strategy use. It revealed that the students did not expect their ESP teachers to know everything about their subject area and admitting ignorance in some specific contexts was not regarded as a flaw in their teachers.

The results of these two research studies reflect what happens in the "normal" ESP class. We can say that most (and probably all) ESP teachers face In-class Subject Knowledge Dilemma (ISKD) situations. In order to survive, they decided to take a risk by offering a response based on uncertain or incomplete knowledge. However, since they lack this kind of knowledge, the risk that they take probably will yield negative results.

However, when I consider the students' opinions of us, a language teacher in an ESP class, I realize that in order to survive in an ESP class, we do not have to take a bad risk. What we have to do is to adapt ourselves, learning to play new roles, the roles of the ESP practitioner.

\section{The Roles of ESP Practitioners}

According to Dudley-Evans and St. John (1998), ESP teaching is extremely varied, so the term "practitioner" is used instead of "teacher" to emphasize that ESP work involves much more than teaching.

The first role is the ESP practitioner as teacher. According to Dudley-Evans and St. John (1998), the role of the ESP teacher is different from the role of the EFL teacher. That is, the teacher is not in the position of being the primary knower of the carrier content of the material; the students may know more about the content than the teacher. In this case, according to Dudley-Evans (1997), the ESP teacher should learn how to learn from and with their students, engaging them in genuinely participatory explorations of discourse domains. If a language teacher accepts his/her changing role in an ESP class, I believe that when we have to face a subject knowledge dilemma, we will be more confident in admitting ignorance, saying that we do not know and are willing to learn from the students, who are the specialists in the field. However, a language teacher has to keep in mind that in an ESP class, we still have the role of language specialist, so we have to make sure that we show our students that we are truly the experts in the field; otherwise, the students may not respect us.

The second role is the ESP practitioner as collaborator. It is likely that language teachers can be more capable of dealing with ESP effectively through collaboration with subject specialists. This kind of cooperation, according to Dudley-Evans and St. John (1998), can be done at three levels: cooperation, collaboration, and team-teaching. The first level is cooperation. At this level, language teachers gather information from the subject specialists. The 
information may include the content of the course, the tasks required of the students, and the expectations of the respective department and its related discourse community about the nature of the communication in the subject. The second level, collaboration, involves the language teacher and the subject specialist working jointly outside the classroom to design ESP class activities or tasks. The third level, which is the fullest collaboration, is when the language teacher and the subject specialist team-teach classes. We can see that this role depends to a great extent on the relationship between us - the language teacher and the people we are asking for help. If we have a good relationship with them, I am quite sure that our life in the ESP class will be a lot easier.

Another role that I think is very important to help us survive in an ESP class is the ESP practitioner as discourse analyst - the ESP teacher should know how to analyze texts and genres. According to Ferguson (1996), much of the public communicative behavior of different disciplines is organized through genres and they are the communicative vehicles through which the language of the discipline is manifested. Swales (1990) emphasizes that understanding the language of a discipline, its discourse and grammar, is likely to be of considerable help in grasping how knowledge of that discipline is constructed. In my opinion, since the main focus of ESP teaching is on the language, the genre-based approach may be a good method for ESP teaching.

\section{Conclusion}

This paper reviews a number of related literature and previous studies concerning the definition of ESP, subject specificity, subject specialist knowledge, strategies for dealing with a lack of subject specialist knowledge, and the roles of the ESP practitioner. These are reviewed in order to find out the answer to the question, "Is it possible that we, who have limited subject specialist knowledge, can settle down happily in this strange and uncharted land?"

The answer to this question becomes clearer, "Yes, we can be a successful dweller in this strange and uncharted land," or Yes, we can be an effective ESP teacher" Deciding to teach an ESP course is like deciding to go into the strange and uncharted land. First, we need to have a clear purpose for going there. The purpose of our ESP teaching is the language, not the content. Thus, as language specialists we are the right persons to go to this land. Second, when going into the new land, it is impossible for us to be natives because we are not. Thus, in ESP teaching we do not have to be (actually cannot be) a subject specialist. However, it is necessary that we adapt ourselves to the new environment. We need to have a positive attitude toward the ESP content, which means that we have to be interested in the subject and be willing to learn more. Further, we have to learn to play many new roles, which are different from the roles we used to play, and we have to keep in mind the famous statement by Helen Keller that "No pessimist ever discovered the secret of the stars, or sailed to an uncharted land, or opened a new doorway for the human spirit." An optimistic language teacher, therefore, will settle down happily in the land of ESP.

\section{References}

Abbott, G. (1983). Training Teachers Of EST: Avoiding Orthodoxy. The ESP Journal, 2(1), 33-6. https://doi.org/10.1016/0272-2380(83)90008-2

Adam-Smiths, D. (1983). ESP Teacher-Training Needs In The Middle East. The ESP Journal, 2(1), 37-8. https://doi.org/10.1016/0272-2380(83)90009-4

Belcher, D. D. (2006). English For Specific Purposes: Teaching To Perceived Needs And Imagined Futures In Worlds Of Work, Study, And Everyday Life. TESOL Quarterly, 40(1), 133-156. https://doi.org/10.2307/40264514

Belcher, D. (2009). What ESP Is And Can Be: An Introduction. In D. Belcher (Ed.), English For Specific Purposes: Theory And Practice (pp. 1-20). Ann Arbor: University Of Michigan Press.

Anthony, L. (2011). Products, Processes And Practitioners: A Critical Look At The Importance Of Specificity In ESP. Taiwan International ESP Journal, 3(2), 1-18.

Bell, T. (1999). Do EAP Teachers Require Knowledge Of Their Students' Specialist Academic Subjects? The Internet TESL Journal, 5(10).

Bhatia, V. K. (1997). Genre-Mixing In Academic Introductions. English For Specific Purposes, 16(3), 181-196. https://doi.org/10.1016/S0889-4906(96)00039-7

Dudley-Evans, T. (1993). Subject Specificity In ESP: How Much Does The Teacher Need To Know Of The Subject? Asp. La Revue Du GERAS, (1), 1-9. https://doi.org/10.4000/asp.4354

Dudley-Evans, T. (1997). Five Questions For LSP Teacher Training. In R. Howard \& G. Brown (Eds.), Teacher Education For Languages For Specific Purposes (pp. 58-67). Clevedon, Avon: Multilingual Matters. 
Dudley-Evans, T., \& St. John, M.-J. (1998). Developments In ESP: A Multi-Disciplinary Approach. Cambridge: Cambridge University Press.

Ewer, J. R. (1983). Teacher Training For EST: Problems And Methods. ESP Journal, 2(1), 9-31. https://doi.org/10.1016/0272-2380(83)90007-0

Ferguson, G. (1997). Teacher Education And LSP: The Role Of Specialised Knowledge. Teacher Education For LSP, 80-89.

Halliday, M. (1994). An Introduction To Functional Grammar (2nd Eds.), London: Edwad Arnold.

Howell, F. S. (2009). English For Science And Engineering At Sophia University. In K. Fukui, J. Noguchi, And N. Watanabe, (Eds.), Towards ESP Bilingualism [In Japanese] (pp. 112-119).

Hutchinson, T., \& Waters, A. (1987). English For Specific Purposes: A Learning-Centred Approach. Cambridge: Cambridge University Press. Osaka: Osaka University Press. https://doi.org/10.1017/CBO9780511733031

Hyland, K. (2002). Specificity Revisited: How Far Should We Go Now? English For Specific Purposes, 21(4), 385-395. https://doi.org/10.1016/S0889-4906(01)00028-X

Mansoor, T, Najmeh, N. \& Mohsen R. (2013). Applying Strategies For Dealing With Lack Of Subject Knowledge: Can Language Teachers Be Effective ESP Teachers? English For Specific Purposes World, $37(13), 1-14$.

Mayers, G. (1991). Lexical Cohesion And Specialized Knowledge In Science And Popula Science Texts. Discourse Processes, 14, 1-26. https://doi.org/10.1080/01638539109544772

Selinker, L. (1979). On The Use Of Informants In Discourse Analysis And Language For Specialized Purposes. International Review Of Applied Linguistics, 17(3), 189-215. https://doi.org/10.1515/iral.1979.17.1-4.189

Spack, R. (1988). Initiating ESL Students Into The Academic Discourse Community: How Far Should We Go? TESOL Quarterly, 22(1), 29-51. https://doi.org/10.2307/3587060

Swales, J. M. (1990). Genre Analysis: English In Academic And Research Settings. Cambridge, UK: Cambridge University Press.

Strevens, P. (1988). ESP After Twenty Years: A Re-Appraisal. In M. Tickoo (Ed.), ESP: State Of The Art (1-13). SEAMEO Regional Language Centre.

Widdowson, H. G. (1983). Learning Purpose And Language Use. Oxford: Oxford University Press.

White, G. (1981). The Subject Specialist And The ESP Teacher. Lexden Papers 2, 9-14

Wu, H., \& Badger, R. G. (2009). In A Strange And Uncharted Land: ESP Teachers' Strategies For Dealing With Unpredicted Problems In Subject Knowledge During Class. English For Specific Purposes, 28, 19-32. https://doi.org/10.1016/j.esp.2008.09.003

Zuck, L.V. And Zuck, J. (1984). The Main Idea: Specialist And Non-Specialist Judgments. Reading For Professional Purposes, 25, 146-53.

\section{Copyrights}

Copyright for this article is retained by the author(s), with first publication rights granted to the journal.

This is an open-access article distributed under the terms and conditions of the Creative Commons Attribution license (http://creativecommons.org/licenses/by/4.0/). 